THE AGE OF MIGRATION 
Also by Stephen Castles

Immigrant Workers and Class Structure in Western Europe (with Godula Kosack)

The Education of the Future (with Wiebke Wüstenberg)

Here for Good: Western Europe's New Ethnic Minorities

(with the assistance of Heather Booth and Tina Wallace)

Mistaken Identity: Multiculturalism and the Failure of Australian

Nationalism (with Bill Cope, Mary Kalantzis and Michael Morrissey)

Australia's Italians: Culture and Community in a Changing Society

(co-edited with Caroline Alcorso, Gaetano Rando and

Ellie Vasta)

The Teeth are Smiling: The Persistence of Racism in Multicultural Australia (with Ellie Vasta)

Also by Mark J. Miller

Foreign Workers in Western Europe: An Emerging Political Force Administering Guestworker Programs: Lessons from Europe (with Phillip L. Martin)

The Unavoidable Issue: US Immigration and Refugee Policy in the 1980s (with Demetrios G. Papademetriou) 


\section{The Age of Migration}

International Population Movements in the

Modern World

Second Edition

Stephen Castles

and

Mark J. Miller 
(C) Stephen Castles and Mark J. Miller 1993, 1998

All rights reserved. No reproduction, copy or transmission of this publication may be made without written permission.

No paragraph of this publication may be reproduced, copied or transmitted save with written permission or in accordance with the provisions of the Copyright, Designs and Patents Act 1988, or under the terms of any licence permitting limited copying issued by the Copyright Licensing Agency, 90 Tottenham Court Road, London W1P 9HE.

Any person who does any unauthorised act in relation to this publication may be liable to criminal prosecution and civil claims for damages.

The authors have asserted their rights to be identified as the authors of this work in accordance with the Copyright, Designs and Patents Act 1988.

First edition 1993

Reprinted three times

Second edition 1998

Published by

MACMILLAN PRESS LTD

Houndmills, Basingstoke, Hampshire RG21 6XS

and London

Companies and representatives throughout the world

ISBN 978-0-333-73245-8 ISBN 978-1-349-26846-7 (eBook)

DOI 10.1007/978-1-349-26846-7

A catalogue record for this book is available from the British Library.

This book is printed on paper suitable for recycling and made from fully managed and sustained forest sources.

Copy-edited and typeset by Povey-Edmondson

Tavistock and Rochdale, England

$\begin{array}{llllllllll}10 & 9 & 8 & 7 & 6 & 5 & 4 & 3 & 2 & 1\end{array}$

$\begin{array}{llllllllll}07 & 06 & 05 & 04 & 03 & 02 & 01 & 00 & 99 & 98\end{array}$ 


\section{Contents}

List of Maps, Tables and Exhibits

vii

Preface to the Second Edition

ix

Acknowledgements to the First Edition xiv

List of Abbreviations $\quad$ xv

1 Introduction 1

2 The Migratory Process and the Formation of Ethnic Minorities

3 International Migration before $1945 \quad 48$

4 Migration to Highly Developed Countries since 1945

5 The Next Waves: The Globalisation of International $\begin{array}{ll}\text { Migration } & 104\end{array}$

6 New Migrations in the Asia-Pacific Region 141

7 Migrants and Minorities in the Labour Force 162

8 The Migratory Process: A Comparison of Australia and Germany

9 New Ethnic Minorities and Society 212

10 Immigrant Politics 253

11 Conclusion: Migration in the New World Disorder 283

Notes 299

Further Reading $\quad 303$

$\begin{array}{ll}\text { Bibliography } & 307\end{array}$

Index $\quad 326$ 


\section{List of Maps, Tables and Exhibits}

Maps

1.1 Global migratory movements from 1973

3.1 Colonial migrations from the seventeenth to the nineteenth centuries

3.2 Labour migrations connected with industrialisation, $1850-1920$

4.1 Global migrations, 1945-73 69

5.1 Migrations from Eastern to Western Europe since $1989 \quad 107$

5.2 Return migration from the Gulf during the 1990-1 Kuwait crisis

5.3 Migrations within and from Africa 126

5.4 Migrations within and from Latin America 132

6.1 Migrations within the Asia-Pacific region 143

\section{Tables}

4.1 Minority population in the main Western European countries of immigration, 1950-75 72

4.2 Foreign resident population in selected OECD countries $\quad 80$

8.1 Australia: immigrant population by birthplace 186

$\begin{array}{lll}8.2 & \text { Foreign residents in Germany } & 187\end{array}$

8.3 Australia, settler arrivals: top 10 countries of birth, 1966-7 and 1994-5 191

9.1 Foreign resident population in France, the Netherlands, Sweden and Switzerland 228

9.2 Naturalisations in selected countries, 1988 and $1995 \quad 239$

\section{Exhibits}

1.1 The Gulf War 11

1.2 Eastern Europe and the collapse of the Berlin Wall 12 
1.3 Ethnic cleansing and conflict in Central Africa 14

3.1 Migration and nation in French history 50

3.2 Forced foreign labour in the Nazi war economy 65

$\begin{array}{ll}\text { 4.1 The German 'guestworker' system } & 71\end{array}$

5.1 Kurdish refugees in Middle East regional conflicts 122

5.2 Labour migration to the Republic of South Africa 128

5.3 Haitian braceros in the Dominican Republic 137

9.1 Minorities in the USA 214

9.2 Minorities in Canada 218

9.3 Minorities in the UK 222

9.4 Minorities in France 226

9.5 Minorities in the Netherlands 230

9.6 Minorities in Switzerland 234

9.7 Minorities in Sweden 236 


\section{Preface to the Second Edition}

The Age of Migration was originally published in 1993, with the aim of providing an accessible overview of global migrations and their consequences for society. In the meantime, international migration has become a major theme of public interest, and a number of excellent comparative works on the topic have been published. None the less, we feel that The Age of Migration still provides a unique perspective, and that its analysis and conclusions have stood the test of time. This second edition updates the work by providing more recent data, describing new developments in migration and minority formation, and providing a more detailed treatment of certain key topics.

The second edition has been substantially rewritten and changed somewhat in structure compared with the original work. Additions, corrections and changes are to be found throughout the text. Chapter 2 has been extended, especially the first part on migration theory. The second part of Chapter 4, which deals with migration to highlydeveloped countries since the mid-1970s, has been thoroughly revised and updated. Chapter 6 of the original version has been expanded and split in two, in response to greater availability of information on emerging areas of migration: Eastern Europe, the Arab region, Africa and Latin America are examined in the new Chapter 5, while the AsiaPacific region is the focus of Chapter 6. The old Chapter 5, which compares the migratory process in two very different countries, Germany and Australia, is now Chapter 8, to link it better to the discussion of the long-term impact of immigration on society and politics in Chapters 9 and 10.

We considered adding a statistical appendix, but refrained, since such figures rapidly become outdated, and are in any case now readily available through the Internet, as well as from the sources given elsewhere in the book. A number of the most relevant Internet sources are listed under 'Further Reading'.

In this new Preface, we want briefly to draw attention to some of the major developments since we wrote the original work. These topics are dealt with in more detail in the book. The most obvious trend is the growing politicisation of international migration issues. The first half of the 1990s saw anti-immigration movements in many countries, 
which sometimes led to racist violence against minorities. Governments too became concerned about their ability to control migration and to manage cultural diversity. These tendencies precipitated some major changes: the 1993 'asylum compromise' in Germany meant abandoning a fundamental tenet of Germany's Basic Law; the change to France's Nationality Code in the same year represented the watering down of the long-standing principle of integration through citizenship; while cuts to welfare rights of legal immigrants in the USA in 1996 questioned the tradition of assimilation of immigrants which is part of the 'American Creed'. On the other hand, several European states have changed their nationality laws to make it easier for immigrants and their children to become citizens.

The politicisation of migration affected new areas too: the 1995 Flor Contemplacion case, in which a Filipino maid was executed for murder in Singapore, led to heated public debates in the Philippines which have been echoed in other labour-exporting countries. What does it mean for national identity if a country is forced to export its most valuable good - its people - for economic reasons? How can a labour-exporting country protect its citizens overseas when most of the power in the global labour market lies with the labour-importing countries? Many people in poorer countries are beginning to question the strategy of development based on migrant remittances and to demand a search for alternatives. New immigration countries, like Italy, Japan and Malaysia, have begun to worry about the consequences of immigration for their societies. The most common responses are increasing restrictiveness through deportation campaigns, border controls and measures to prevent permanent settlement. Many governments still follow a strategy of denial: by tacitly tolerating illegal immigration, and ignoring the likelihood of settlement, they avoid facing up to difficult decisions.

One consequence of the politicisation of international migration has been attempts at international cooperation. In Western Europe, the Schengen Agreement and a range of other multilateral measures have had some effect in reducing immigration. At the beginning of the 1990s, Western Europe was gripped by fears of uncontrollable mass migrations from the east and the south. There have indeed been significant movements, but the predicted mass influx of impoverished people did not take place. However, it is not clear if this was because of multilateral efforts, border control measures, stabilisation of the situation in Eastern Europe, or because migrants lacked the social networks and cultural capital required for migration. Probably all these factors played a part. 
Debate on international migration has occurred in other regions, especially in economic fora such as the Asia-Pacific Economic Cooperation (APEC), the North American Free Trade Area and the Latin American Southern Common Market (MERCOSUR). However, no effective mechanisms have been devised even for monitoring migrations in these regions, let alone for regulating them.

There is still no global agency responsible for observing international migration and coordinating responses. The United Nations (UN) has played only a limited role, partly due to problems of demarcation between such agencies as the International Labour Organisation (ILO), the United Nations High Commission for Refugees (UNHCR) and the UN Population Division. The UN's main initiative on migration - the 1990 Convention on the Rights of All Migrant Workers and their Families - has been ratified by only a handful of countries. There are many other international instruments on migrant workers, going back to the ILO Convention of 1949, and including declarations and agreements by the Council of Europe, the European Union (EU) and a range of other bodies. These have had an important role in setting standards for the rights and treatment of migrants, but remain unenforceable and are ignored by many governments. The world is still a long way from a universal system of rights for migrants.

The 1990s have seen the emergence of new types of migration and the entry of ever more countries into the international migration arena. Labour markets for both skilled and unskilled work are being rapidly globalised. The mobility of highly-skilled personnel, usually on a temporary basis, is encouraged by most governments. Lower-skilled workers are often not officially welcomed, even where there is strong employer demand; the result is increased illegal migration, often organised by labour recruiters or migration brokers (the so-called 'migration industry'). One of the most significant quantitative developments is the rapid growth of labour migration to the fast-growing economies of Asia. Africa has also had large new labour migrations, such as the inflows into post-apartheid South Africa. In Latin America, both intra-regional flows and migration to North America have continued to grow. Despite the recent restrictiveness in Western Europe, political, economic and demographic factors are leading some countries to consider new forms of labour recruitment.

A surprising development is the expansion of domestic service both in developed countries where it had almost disappeared, and in fastgrowing economies (like Hong Kong or Singapore), where immigrant servants allow local women to take up new employment opportunities. 
The Filipino, Sri Lankan or Colombian maid has become an almost ubiquitous emblem of prosperity from Toronto to Tokyo, from Rome to Riyadh. The rebirth of domestic service is part of two broader interconnected trends: the increasing polarisation of labour markets on the basis of skill, and the growing feminisation of international migration.

Global refugee flows seem to have declined somewhat following the rapid expansion of the late 1980s and early 1990s, but large-scale involuntary movements continue around such trouble spots as Afghanistan and Burma, while the whole of Asia fears the potential for mass flows if conflicts erupt in North Korea, Indonesia or China. There have been return flows of refugees where political stability has improved for example in Mozambique and Central America - but also massive new refugee movements, of which the most dramatic was that of 1995-7 involving the central Africa countries of Rwanda, Burundi, Zaire and Tanzania. Large-scale movements still continue within and between the successor states of the former Soviet Union. Motivations are both political and economic, but the essential cause is the fundamental dislocation brought about by the end of communism. Mass movements of asylum seekers from parts of the former Yugoslavia to Western Europe were a feature of the early 1990s. Now return movements are being initiated by receiving governments.

As for incorporation of new minorities into society, the last few years have seen heated debates, but little progress in finding viable solutions. There is growing awareness that permanent exclusion of immigrants (and their descendants) from citizenship leads to dangerous political and social divisions. Yet the fundamental controversy on assimilation versus multiculturalism is far from being resolved. In some countries there has been a trend away from multiculturalism, with a renaming or watering down of multicultural policies in Canada, Australia, the Netherlands and Sweden. Yet the social forces which led to multilingualism and cultural pluralism still exist, so that a return to assimilationism seems improbable. Other countries have officially rejected multicultural policies, but have sometimes tacitly introduced them in such areas as education or social welfare. Certainly, public discussion of multiculturalism has grown in countries such as the USA, France and Germany. But there is also growing realisation that multiculturalism may not just mean allowing colourful folkloric practices, but also accepting the possibility of cultural and institutional change. Many people (including political leaders) find this too unsettling to contemplate. 
International migration has become a major force of social transformation in the modern world. Where migration flows are large, they affect the whole of both the sending and receiving societies. Migrants develop transnational identities which question traditional notions of distinct national belonging. The age of migration is just beginning.

Finally, the authors wish to acknowledge the many valuable criticisms of the original book made by reviewers and colleagues, although it has not been possible to respond to all of them in the new edition. We thank Colleen Mitchell and Lyndal Manton (University of Wollongong) and Mary McGlynn (University of Delaware) for help in preparing the revised text. Most of the maps have been redrawn to improve clarity by David Martin of Cadmart Drafting, Wollongong. Thanks also to our publisher Steven Kennedy for his continued support.

Stephen Castles

MARK J. Miller 


\section{Acknowledgements to the First Edition}

The idea for this book took shape at a conference on Minority Language Rights and Minority Education sponsored by the Western Societies Program of Cornell University in 1988. A conference on EastWest migration sponsored by the European Culture Research Centre of the European University Institute in Florence in 1991 again enabled the authors to meet to discuss the project. We would like to thank our publisher, Steven Kennedy, for his advice and encouragement, as well as his patience throughout the project, and John Solomos and Fred Halliday for their constructive and helpful comments.

Stephen Castles wishes to thank Ellie Vasta of the Department of Sociology, University of Wollongong, for reading the whole manuscript and providing many useful suggestions, as well as giving a great deal of support and encouragement. Jock Collins of the University of Technology, Sydney, also read parts of the work and made valuable comments. Colleen Mitchell of the Centre for Multicultural Studies (CMS), University of Wollongong, edited the manuscript and helped prepare the bibliography. Kim McCall of CMS worked on the tables, prepared the final manuscript and gave administrative support throughout. Thanks also to my colleagues at CMS who put up with my preoccupation with this task and provided useful ideas.

Mark Miller wishes to thank Gloria Parisi, Mary McGlynn, Aaron C. Miller and Debjani Bagchi, in particular, for the assistance they provided during the preparation of the manuscript. He also wishes to thank the clerical staff of the Department of Political Science and International Relations at the University of Delaware and that of the Center for Migration Studies in Staten Island, New York, for their unflagging assistance. A leave of absence granted by the University of Delaware in Autumn 1991 greatly facilitated completion of this book. The maps were drawn by David Martin of Cadmart Drafting, Wollongong. 


\section{List of Abbreviations}

AAE

ABS

ALP

ANC

APEC

BfA

BIMPR

BIR

CDU

CGT

CIA

CMS

CSIMCED

CSL

DIMA

EC

ECOWAS

ECSC

EFTA

EU

EVW

FAS

GATT

$\mathrm{HCI}$

HLMs

IFOR

INS

IOM

IRCA
Amicale des Algériens en Europe

Australian Bureau of Statistics

Australian Labour Party

African National Congress

Asia-Pacific Economic Cooperation

Bundesanstalt für Arbeit (Federal Labour Office)

Bureau of Immigration, Multicultural and Population

Research

Bureau of Immigration Research

Christian Democratic Union

Confédération Générale du Travail

Central Intelligence Agency

Centre for Multicultural Studies

The Commision for the Study of International

Migration and Cooperative Economic Development

Confédération des Syndicats Libres

Department of Immigration and Multicultural Affairs

European Community

Economic Community of West African States

European Convention on Security and Cooperation in Europe

European Free Trade Association

Eurpean Union

European Voluntary Worker

Fonds d'Action Sociale (Social Action Fund)

General Agreement on Tariffs and Trade

Haut Conseil a l'Intégration (High Council for Integration)

habitations à loyers modestes (public housing societies)

Implementation Force in Bosnia following the 1995

Dayton Agreement

Immigration and Naturalization Service

International Organisation for Migration

Immigration Reform and Control Act 


$\begin{array}{ll}\text { KDP } & \text { Kurdish Democratic Party } \\ \text { KPP } & \text { Kurdish Workers Party } \\ \text { MERCOSUR } & \text { Latin American Southern Common Market } \\ \text { NAFTA } & \text { North American Free Trade Agreement } \\ \text { NATO } & \text { North Atlantic Treaty Organisation } \\ \text { NICs } & \text { newly industrialising countries } \\ \text { OCW } & \text { overseas contract worker } \\ \text { ONI } & \text { Office National d'Immigration (National Immigration } \\ & \text { Office) } \\ \text { OPEC } & \text { Organisation of Petroleum Exporting Countries } \\ \text { PCF } & \text { French Communist Party } \\ \text { PRD } & \text { Party of the Democratic Revolution } \\ \text { PUK } & \text { Patriotic Union of Kurdistan } \\ \text { RSA } & \text { Republic of South Africa } \\ \text { SAC } & \text { Special Assistance Category } \\ \text { SGI } & \text { Société Générale d'Immigration } \\ \text { SHP } & \text { Special Humanitarian Programme } \\ \text { SPD } & \text { Social Democratic Party } \\ \text { UN } & \text { United Nations } \\ \text { UNHCR } & \text { United Nations High Commisions for Refugees } \\ \text { WTO } & \text { World Trade Organisation } \\ \text { ZEP } & \text { zones d'éducation prioritaire (educational priority } \\ & \text { zones) }\end{array}$

